\title{
Anti-inflammatory, antipyretic and analgesic effect of Achillea millefolium and Salix plants
}

\author{
S. E. El-Sadek ${ }^{1}$, A. A. M. El-Gendy ${ }^{1^{*}}$, M. A. Tohamy ${ }^{1}$, M. A. Abd El-Aa ${ }^{2}$ \\ ${ }^{1}$ Pharmacology Deparment, Faculty of Veterinary Medicine, Beni-Suef University, Egypt \\ ${ }^{2}$ Animal Health Research Institute, Beni-suef, Egypt
}

\begin{abstract}
The Anti-inflammatory, antipyretic and analgesic effect of Achillea millefolium and Salix were investigated in rats and mice. The extracts of Achillea millefolium exerted significant antiinflammatory, antipyretic and analgesic effects. Also potentiated the sleeping time of thiopental sodium in mice. The doses used were 10.375 and 20.75 (watery extract) and 9.5 and $19 \mathrm{mg} / 100 \mathrm{gm}$ b.wt. (ethanolic extract). Salix produced the same effects at doses of 0.0825 and 0.165 (watery extract) and 0.0850 and $0.170 \mathrm{mg} / 100 \mathrm{gm}$ b.wt. (ethanolic extract). The extracts of both plants have an anti-inflammatory, antipyretic and analgesic effect.
\end{abstract}

One of the most important fields of medicine is the herbal treatment. The back to nature invitation forced us to investigate plants used in folk medicine as Achillea millefolium and Salix. Achillea millefolium had been used in popular medicine for its anti-hemorrhagic, analgesic and wound healing effects (Chandler et al., 1982). It was used by Northern European and North American native peoples as a contraceptive, abortifacient and emmenagogue (Chandler et al., 1982). The flower heads of Achillea millefolium contain the most active fraction that posses antiinflammatory activity (Goldberg et al., 1969). Extracts of the bark of Salix species had been used for treating fever, mild rheumatic complains and pain including headache. Salix contains active principle salicin, which is the pro-drug of various salicylate derivatives (Krivoy et al., 2001). The bark of Salix has antiinflammatory properties (Schilcher, 2000).

The aim of this work was designed to investigate the effect of both water and ethanolic extracts of Achillea millefolium and Salix as anti-inflammatory, antipyretics and analgesics. The effect of extracts of both plants on sleeping time was also investigated.

\section{Materials and Methods}

Animals. Ninety mature albino rats weighing 150-205 gm and hundred mice weighing 20-25 gm b.wt. of both sexes were obtained from Helwan Laboratory Animal Unit. Animals were kept and housed in plastic cages under hygienic conditions, fed on balanced ration and observed

\footnotetext{
* Corresponding author. Tel.: +20 105380875; fax: +20822327982 .

E-mail address: elgendyab@yahoo.com (A.A.M. El-Gendy).
}

two weeks before use.

Chemicals and drugs. Ethanol $95 \%$ (El-Nasr Pharmaceutical Chemical Co., Egypt), tween 80 solution (Fisher Chem. Alter Guide), dipyrone (Novalgin)® ampules (Hochest, Germany), paracetamol tablets (Pharco Co.), diclofenac sodium (Voltaren ampules) ${ }^{\circledR}$ (Ciba Gigey) and thiopental sodium (Nesdonal) ${ }^{\circledR}$ (Specia-Paris, France, MPH) were used in this study.

Plant extracts.

1-Acillea millefolium, the aerial parts of the plant was shade, dried and ground into fine powder and extracted. (a) Water extract was prepared by boiling $100 \mathrm{gm}$ of dry powder with $300 \mathrm{ml}$ distilled water for 10-15 min. Sieved and then the extract was evaporated until obtaining paste then dried. Solid extract was weighted and $10 \mathrm{gm}$ were dissolved into $100 \mathrm{ml}$ distilled water according to Chaplins'ka and Golovkin, (1962). (b) Ethanolic extract was prepared by putting 30 gm of dry powder in Soxlet apparatus with $95 \%$ ethanol till obtain ethanolic extract then evaporate the extract until obtaining paste. Weigh the paste and dilute $10 \mathrm{gm}$ with $100 \mathrm{ml}$ tween 80 solution $1 \%$ as a solvent.

2-The bark of Salix trees at least 4 years old was shade, dried and ground into fine powder and extracted as Acillea millefolium.

Anti-inflammatory effect. The method described by Winter et al. (1962) was adopted. Forty mature albino rats of both sexes weighing 150-200 gm were used. They were divided into 10 equal groups (4 rats in each). Edema in rats paw was induced by injecting $0.1 \mathrm{ml}$ of Brewer's yeast $20 \%$ suspension in physiological saline in paw skin (Randall and Sellitto, 1957). After four 
hours the thickness of the rat paw was measured using skin caliber to detect the inflammation achieved by the Brewer's yeast. The $1^{\text {st }}$ group was left as control, while the $2^{\text {nd }}$ group was given intraperitoneally diclofenac sodium (Voltaren) ${ }^{\circledR}$ ampoules in doses of $3.3 \mathrm{mg} / 100$ gm b.wt. as an anti-inflammatory agent. The $3^{\text {rd }}$, $4^{\text {th }}, 5^{\text {th }}$ and $6^{\text {th }}$ groups of Acillea millefolium and Salix were injected intraperitoneally with water extract in doses of 10.375 and 20.75, 0.0825 and $0.165 \mathrm{mg} / 100 \mathrm{gm}$ b.wt., respectively. While the $7^{\text {th }}, 8^{\text {th }}, 9^{\text {th }}$ and $10^{\text {th }}$ groups were injected intraperitoneally with ethanolic extract at doses of 9.5 and $19,0.0850$ and $0.170 \mathrm{mg} / 100 \mathrm{gm}$ b.wt., respectively. The thickness of the paw was measured after 3 and 6 hours after administration. The thickness of the paw measured before administration of Brewer's yeast was subtracted from the value obtained in order to estimate the edematous swelling. The activity of the drug was estimated from the percent of decrease in the paw thickness compared with control group.

Antipyretic effect. The antipyretic effect of Acillea millefolium and Salix (watery and ethanolic extracts) on the rats of feverish body temperature was determined using the method described by (Alperman,1972). Fifty fasting mature albino rats weighing 200-250gm b.wt. of both sexes were divided into 10 groups ( 5 rats in each). Four groups were used for each plant extract. Hyperthermia was induced by subcutaneous injection of $20 \%$ Brewer's yeast suspension in physiological saline in the paws (Teotino et al., 1963) in a dose of $0.15 \mathrm{gm} / 100$ gm b.wt. After 17 hours, the body temperature of each rat was recorded rectally using medical thermometer. The $1^{\text {st }}$ group served as a control, injected with saline. The $2^{\text {nd }}$ group was injected intraperitoneally with dipyrone (Novalgin) ${ }^{\circledR}$ ampoules in a dose of $5 \mathrm{mg} / 100 \mathrm{gm} \mathrm{b}$.wt. as a standard antipyretic. The $3^{\text {rd }}, 4^{\text {th }}, 5^{\text {th }}$ and $6^{\text {th }}$ groups were injected with water extract of Acillea millefolium and Salix in doses of 10.375 and $20.75,0.0825$ and $0.165 \mathrm{mg} / 100$ gm b.wt., respectively. While the $7^{\text {th }}, 8^{\text {th }}, 9^{\text {th }}$ and $10^{\text {th }}$ groups were injected with ethanolic extract at doses of 9.5 and $19,0.0850$ and $0.170 \mathrm{mg} / 100$ gm b.wt. intraperitoneally of Acillea millefolium and Salix, respectively. The body temperature of each rat was recorded every half-hour for four hours.

Analgesic effect.The analgesic effect of Acillea millefolium and Salix (watery and ethanolic extracts) were determined using the hot plate method described by (Janssen and Jageneau, 1957) and modified by (Jacob and Bosovski, 1961). Fifty mature mice of both sexes weighing 20-25 gm were divided into 10 groups (5 mice in each). Four groups were used for each plant extract. The $1^{\text {st }}$ group left as control, while the $2^{\text {nd }}$ group was given orally paracetamol tablets in a dose of $50 \mathrm{mg} / 100 \mathrm{gm} \mathrm{b}$.wt. as an analgesic. The $3^{\text {rd }}, 4^{\text {th }}, 5^{\text {th }}$ and $6^{\text {th }}$ groups of Acillea millefolium and Salix were given water extract in doses of 10.375 and $20.75,0.0825$ and 0.165 $\mathrm{mg} / 100$ gm b.wt., respectively. While the $7^{\text {th }}, 8^{\text {th }}$, $9^{\text {th }}$ and $10^{\text {th }}$ groups were injected with ethanolic extract at doses of 9.5 and $19,0.0850$ and 0.170 $\mathrm{mg} / 100 \mathrm{gm}$ b.wt., respectively. After 5 minutes each mouse was placed in beaker of 2 liters capacity immersed in water bath at $56^{\circ} \mathrm{C}$ controlled thermostatically. The time elapsed until the mouse licks its paw or jumps was considered as the reaction time and recorded as a measure of analgesic activity. Reaction time was recorded after 10, 20, 30, 60, 90 and $120 \mathrm{~min}$. post-treatment. The reaction time was calculated and used as response to the given dose at the respective time interval.

Effect on sleeping time. The method described by Alperman, (1972) was adopted. Fifty mature mice of both sexes weighing 20-25 gm.b.wt. were divided into 10 equal groups $(5$ mice in each). Five groups were used for each plant. All animals were injected with thiopental sodium (Nesdonal) ${ }^{\circledR} 10 \mathrm{mg} / 100 \quad \mathrm{gm}$ b.wt. in saline solution $2.5 \%$ intra-peritoneally. After 60 minutes, two groups ( $1^{\text {st }}$ group in each plant) were lifted as control (injected with saline solution intra-peritoneally), while the $3^{\text {rd }}, 4^{\text {th }}, 5^{\text {th }}$ and $6^{\text {th }}$ groups of Acillea millefolium and Salix were injected with water extract in doses of 10.375 and $20.75,0.0825$ and $0.165 \mathrm{mg} / 100 \mathrm{gm}$ b.wt., respectively. The $7^{\text {th }}, 8^{\text {th }}, 9^{\text {th }}$ and $10^{\text {th }}$ groups were injected with ethanolic extract at doses of 9.5 and $19,0.0850$ and $0.170 \mathrm{mg} / 100$ gm b.wt., respectively. Time from loosing till remaining of the righting reflexes was considered as the sleeping time.

The obtained results were statistically analyzed using student " $\mathrm{t}$ " test according to Snedecor, (1969) and were expressed as mean and standard error (SE).

\section{Results}

The antipyretic and analgesic effects of extracts of both Achillea millefolium (watery 10.375 and 20.75 and ethanolic 9.5 and $19 \mathrm{mg} / 100 \mathrm{gm} \mathrm{b} . w \mathrm{t}$.) and Salix (watery 0.0825 and 0.165 and ethanolic 0.0850 and $0.170 \mathrm{mg} / 100 \mathrm{gm}$ b.wt.) 

Table (1): Mean $(\underline{+S . E)}$ anti-inflammatory effect of Achillea millefolium and Salix extracts given $I / P$ to rats $(n=4)$.

\begin{tabular}{|c|c|c|c|c|c|c|c|c|c|}
\hline \multirow[b]{2}{*}{ Extract } & \multirow[b]{2}{*}{ Plant } & \multirow[b]{2}{*}{ Group } & \multirow{2}{*}{$\begin{array}{c}\text { Dose } \\
\text { (mg/100 } \\
\text { gm } \\
\text { b.wt) }\end{array}$} & \multirow{2}{*}{$\begin{array}{c}\text { Thickness of } \\
\text { paw (mm) } \\
\text { before } \\
\text { Brewer's } \\
\text { yeast } \\
\text { injection }\end{array}$} & \multirow[b]{2}{*}{ Initial } & \multicolumn{4}{|c|}{ Thickness of paw (mm) } \\
\hline & & & & & & $3 \mathbf{h}$ & $\%$ & $6 h$ & $\%$ \\
\hline \multirow{2}{*}{\multicolumn{2}{|c|}{$\begin{array}{l}\text { Control } \\
\text { lofenac sod. }\end{array}$}} & $1^{\text {st }}$ & - & $2.16 \pm 0.05$ & $7.62 \pm 0.07$ & $7.2 \pm 0.04$ & 5.4 & $6.98+0.05$ & 8.4 \\
\hline & & $2^{\text {nd }}$ & 3.3 & $2.25+0.05$ & $7.77+0.06$ & $5.8+0.06^{* *}$ & 25.8 & $3.92+0.10$ & 49.5 \\
\hline \multirow{2}{*}{\multicolumn{2}{|c|}{ Achillea }} & $3^{\text {rd }}$ & 10.375 & $2.15+0.06$ & $7.02+0.10^{* *}$ & $5.8 \pm 0.05 * *$ & 18.1 & $5.32 \pm 0.02 * *$ & 24.2 \\
\hline & & $4^{\text {th }}$ & 20.750 & $2.15+0.06$ & $7.07+0.07 * *$ & $5.1 \pm 0.04 * *$ & 27.4 & $4.8+0.07 * *$ & 31.6 \\
\hline Water & \multirow{2}{*}{ Salix } & $5^{\text {th }}$ & 0.0825 & $2.4+0.04$ & $7.5+0.04$ & $6.8 \pm 0.03 * *$ & 18.8 & $6.1 \pm 0.04 * *$ & 24.2 \\
\hline & & $6^{\text {th }}$ & 0.165 & $2.3+0.10$ & $7.4+0.06$ & $5.9 \pm 0.10^{* *}$ & 28.4 & $5.4 \pm 0.09 * *$ & 34.7 \\
\hline \multirow{4}{*}{ Ethanolic } & \multirow{2}{*}{ Achillea } & $7^{\text {th }}$ & 9.5 & $2.19 \pm 0.03$ & $7.02 \pm 0.10^{* *}$ & $5.7 \pm 0.06 * *$ & 9.3 & $5.32 \pm 0.04 * *$ & 18.6 \\
\hline & & $8^{\text {th }}$ & 19 & $2.15 \pm 0.03$ & $7.07 \pm 0.10^{* *}$ & $5.02 \pm 0.09 * *$ & 20.1 & $4.52 \pm 0.10^{* *}$ & 27.7 \\
\hline & \multirow[b]{2}{*}{ Salix } & $\begin{array}{l}0^{0} \\
9^{\text {th }}\end{array}$ & 0.0850 & $2.3+0.09$ & $7.4 \pm 0.04 *$ & $6.7 \pm 0.05 * *$ & 9.18 & $5.9 \pm 0.08 * *$ & 19.5 \\
\hline & & $10^{\text {th }}$ & 0.170 & $2.3 \pm 0.08$ & $7.2 \pm 0.08 * *$ & $5.7 \pm 0.19^{* *}$ & 20.1 & $5.2 \pm 0.11^{* *}$ & 27.7 \\
\hline
\end{tabular}

$* \mathrm{p}<0.05 \quad * * \mathrm{p}<0.01$

were recorded in Tables (1) and (2), respectively. Both plantsin different extracts produced significant anti-inflammatory effect as reflected by decrease in paw thickness (Table 3). Both watery and ethanolic extracts of Achillea millefolium and Salix produced significant $(p<0.01)$ increase in the sleeping time of thiopental sodium in mice when compared with control (Table 4).

\section{Discussion}

Both watery and ethanolic extracts of Achillea millefolium produced a significant decrease in body temperature in feverish rats at doses of $10.375,20.750$ and $9.5,19 \mathrm{mg} / 100 \mathrm{gm}$ b.wt., respectively. This indicated that the extracts have antipyretic effect. These results are in agreement with those obtained by Kudrica and Glowniak (1967). They were attributed the antipyretic action of Achillea millefolium to its flavonoids. Moreover, this result similar to that obtained by Tierra and Lesley (1992). They were stated that Achillea millefolium has antipyretic effect.

Both watery and ethanolic extracts of Salix induced an antipyretic effect which recorded at doses of $0.0825,0.160$ and $0.0850,0.170$ $\mathrm{mg} / 100$ gm b.wt., respectively. These results agreed with that obtained by Kolodziej (1990), who reported that isolation and characterization of four dimeric and five trimeric procyanidins from Salix bark claimed to have antipyretic effect. Also similar effects approved by Thapliyal and Bahuguna (1993) and Masika et al. (1997). The antipyretic effect interpreted by Krivoy et al. (2001), they reported that white yellow bark (Salix bark) contain a variety of chemical constituents, the main one studied being salicin which is metabolically converted in the body to the aspirin metabolite, salicylic acid. Salicylates have antipyretic (fever lowering) effect.

Achillea millefolium (watery and ethanolic extracts) induced a significant analgesic effects at doses used. These findings agreed with Petcu and Anderonescu (1978) and Tierra and Lesley (1992). The analgesic effect of the extract explained by Levine (1978) who mentioned that the analgesic effect may be due to inhibition of synthesis of prostaglandin and as a result prevent the sensitivity of pain receptors.

Analgesic effect of watery and ethanolic extracts of Salix was recorded at doses of $0.0825,0.165$ and $0.0850,0.170 \mathrm{mg} / 100 \mathrm{gm}$ b.wt., respectively. These results are in accordance with those obtained by Whang et al. (1995). They were stated that the bark of Salix gilgiana used as an analgesic. They mentioned that this action is may be due to dimeric and trimeric procyanidins. Also, Kolodziej (1990) showed that isolation and characterization of four dimeric and five trimeric procyanidins from Salix bark claimed to have analgesic effect. Furthermore, Eisenberg et al. (2000) and Heide et al. (2000) mentioned that Salix bark extracts produced analgesic activity in patients with osteoarthritis and effective in alleviating low 

Table (2): Mean $( \pm$ S.E) antipyretic effect of Achillea millefolium and Salix extracts given $\mathbf{I} / \mathbf{P}$ to hyperthermic rats $(\mathrm{n}=5)$.

\begin{tabular}{|c|c|c|c|c|c|c|c|c|c|c|c|c|c|}
\hline \multirow{2}{*}{ 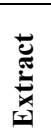 } & \multirow{2}{*}{$\frac{\vec{E}}{a}$} & \multirow[b]{2}{*}{ Group } & \multirow{2}{*}{$\begin{array}{c}\text { Dose } \\
\text { (mg/ 100 } \\
\text { g. b.wt) }\end{array}$} & \multirow{2}{*}{$\begin{array}{c}\text { Temperature } \\
\text { before Bewer's } \\
\text { yeast injection }\end{array}$} & \multirow{2}{*}{$\begin{array}{l}\text { The initial } \\
\text { temperature }\end{array}$} & \multicolumn{8}{|c|}{ Rectal temperature $C^{\circ}$ (Mean+S.E.) after (time/min.) } \\
\hline & & & & & & 30 & 60 & 90 & 120 & 150 & 180 & 210 & 240 \\
\hline \multirow{2}{*}{\multicolumn{2}{|c|}{ Control }} & & & 37.11 & 38.21 & 38.11 & 38.03 & 38.14 & 38.17 & 38.16 & 38.13 & 38.15 & 38.14 \\
\hline & & $1^{\text {st }}$ & - & \pm 0.1 & +0.13 & \pm 0.13 & +0.18 & +0.15 & \pm 0.12 & +0.03 & +0.14 & +0.17 & +0.16 \\
\hline \multirow{2}{*}{\multicolumn{2}{|c|}{ Dipyrone }} & $2^{\text {nd }}$ & 5 & $\overline{3} 7.4$ & $\overline{3} 8.96$ & $\overline{3} 8.32$ & $\overline{3} 7.98$ & $37.5 * *$ & $3 \overline{7} .42 * *$ & $3 \overline{7} .26 * *$ & $3 \overline{7} .22 * *$ & $3 \overline{7} .16^{* *}$ & $\overline{37} .12 *$ \\
\hline & & & 5 & \pm 0.07 & \pm 0.04 & \pm 0.05 & \pm 0.081 & \pm 0.32 & \pm 0.038 & \pm 0.24 & \pm 0.020 & \pm 0.024 & \pm 0.38 \\
\hline \multirow{8}{*}{ 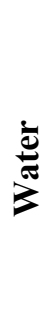 } & \multirow{4}{*}{ 异 } & $3^{\text {rd }}$ & 10375 & 37.44 & 39.3 & 39.2 & 39.1 & 39.02 & 38.84 & 38.12 & 38 & $37.5^{*}$ & $37.5 * *$ \\
\hline & & 5 & $10.5 / 5$ & \pm 0.04 & \pm 0.05 & \pm 0.03 & \pm 0.031 & \pm 0.021 & \pm 0.024 & \pm 0.124 & \pm 0.089 & \pm 0.10 & \pm 0.07 \\
\hline & & $A^{\text {th }}$ & & 37.48 & 39.3 & 39.2 & 39.04 & 38.86 & 38.74 & 38 & $37.7 *$ & $37.5 * *$ & $37.5 * *$ \\
\hline & & $4^{\text {III }}$ & 20.750 & \pm 0.02 & \pm 0.09 & \pm 0.07 & \pm 0.67 & \pm 0.06 & \pm 0.067 & \pm 0.063 & \pm 0.07 & \pm 0.031 & \pm 0.07 \\
\hline & \multirow{4}{*}{$\stackrel{\mathscr{E}}{\stackrel{\mathscr{V}}{\mathscr{V}}}$} & $5^{\text {th }}$ & & 37.52 & 39.4 & 39.12 & $\overline{3} 8.96$ & $\overline{3} 8.82$ & 38.58 & 38 & 37.78 & $37.5 * *$ & $3 \overline{7} .42 * *$ \\
\hline & & & 0.0825 & +0.02 & +0.09 & \pm 0.05 & \pm 0.050 & +0.048 & +0.037 & +0.07 & +0.08 & \pm 0.063 & \pm 0.066 \\
\hline & & $6^{\text {th }}$ & & 37.44 & 39.2 & $\overline{38} 8.96$ & 38.8 & 38.54 & 38.3 & $37.8 * *$ & $37.6^{*}$ & $\overline{3} 7.5^{* *}$ & $37.3^{* *}$ \\
\hline & & 6 & 0.165 & \pm 0.04 & \pm 0.06 & \pm 0.05 & \pm 0.044 & \pm 0.04 & \pm 0.054 & \pm 0.089 & \pm 0.089 & \pm 0.044 & \pm 0.063 \\
\hline \multirow{8}{*}{ 兽 } & \multirow{4}{*}{ 㟒 } & $7^{\text {th }}$ & 05 & 37.5 & 39.4 & 39.2 & 39.02 & $\overline{3} 8.82$ & 38.7 & 38.6 & 38.3 & $37.6^{*}$ & 37.5 \\
\hline & & 7 & 9.5 & \pm 0.03 & \pm 0.04 & \pm 0.03 & \pm 0.02 & \pm 0.02 & \pm 0.031 & \pm 0.031 & \pm 0.07 & \pm 0.054 & \pm 0.089 \\
\hline & & $8^{\text {th }}$ & 19 & 37.5 & 39.4 & 39.34 & 39.14 & 38.92 & 38.64 & 38.2 & 37.8 & $37.5^{* *}$ & $37.5^{* *}$ \\
\hline & & & 19 & \pm 0.03 & \pm 0.04 & \pm 0.05 & \pm 0.05 & \pm 0.058 & \pm 0.092 & \pm 0.083 & \pm 0.089 & \pm 0.054 & \pm 0.054 \\
\hline & \multirow{4}{*}{$\stackrel{\mathscr{V}}{\mathscr{N}}$} & $9^{\text {th }}$ & & 37.52 & 39.4 & 39.18 & 39.02 & 38.8 & 38.6 & 38.2 & 37.8 & $37.6^{*}$ & $37.4 * *$ \\
\hline & & $9^{14}$ & 0.0850 & \pm 0.02 & \pm 0.04 & \pm 0.03 & \pm 0.020 & \pm 0.054 & \pm 0.044 & \pm 0.083 & \pm 0.054 & \pm 0.031 & \pm 0.044 \\
\hline & & $10^{\text {th }}$ & 0.170 & $\overline{3} 7.48$ & 39.3 & 39.1 & 38.82 & 38.6 & 38.2 & 38 & $\overline{3} 7.6^{* *}$ & $\overline{37} .42 * *$ & $\overline{3} 7.4 * *$ \\
\hline & & $10^{\circ}$ & 0.170 & \pm 0.02 & \pm 0.06 & \pm 0.09 & \pm 0.058 & \pm 0.063 & \pm 0.07 & \pm 0.031 & \pm 0.044 & +0.058 & +0.054 \\
\hline
\end{tabular}


Table (3): Mean $( \pm$ S.E) analgesic effect of Achillea millefolium and Salix extracts given $\mathbf{I} / \mathbf{P}$ to mice using hot plate method $(\mathrm{n}=5)$.

\begin{tabular}{|c|c|c|c|c|c|c|c|c|c|}
\hline \multirow{2}{*}{ 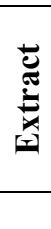 } & \multirow{2}{*}{$\frac{\vec{E}}{\vec{a}}$} & \multirow{2}{*}{ 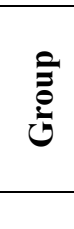 } & \multirow{2}{*}{$\begin{array}{c}\text { Dose } \\
\text { (mg/100 } \\
\text { gm b.wt) }\end{array}$} & \multicolumn{6}{|c|}{ Reaction time (minutes) } \\
\hline & & & & 10 & 20 & 30 & 60 & 90 & 120 \\
\hline \multirow{6}{*}{ 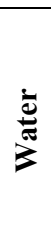 } & Control & $1^{\text {st }}$ & - & $7.29 \pm 0.01$ & $7.65+0.02$ & $7.81 \pm 0.02$ & $7.86+0.023$ & $7.87 \pm 0.01$ & $7.87 \pm 0.014$ \\
\hline & Paracetamol & $2^{\text {nd }}$ & 50 & $7.47 \pm 0.02 * *$ & $8.35 \pm 0.02 * *$ & $9.57 \pm 0.01 * *$ & $10.91 \pm 0.010 * *$ & $12.52 \pm 0.04 * *$ & $14.35 \pm 0.020^{* *}$ \\
\hline & Achillea & $3^{\text {rd }}$ & 10.375 & $7.5 \pm 0.05 *$ & $7.8 \pm 0.02 * *$ & $7.8+0.02$ & $8.0 \pm 0.040 *$ & $8.1 \pm 0.04$ & $8.25+0.104 * *$ \\
\hline & & $4^{\text {th }}$ & 20.750 & $7.8+0.04 * *$ & $7.92+0.02 * *$ & $8.02+0.06^{*}$ & $8.15 \pm 0.028 * *$ & $8.2 \pm \overline{0} .04 * *$ & $8.30+0.040 * *$ \\
\hline & Salix & $5^{\text {th }}$ & 0.0825 & $7.4 \overline{7}+0.04 * *$ & $7.8+0.01$ & $7.8+0.08$ & $10.02+0.085 * *$ & $8 . \overline{1}+0.05$ & $13.7 \pm 0.070 * *$ \\
\hline & & $6^{\text {th }}$ & 0.165 & $7.77 \pm 0.06^{* *}$ & $7.9 \pm 0.1$ & $8.22 \pm 0.13 *$ & $10.55 \pm 0.086^{* *}$ & $8.52 \pm 0.07 * *$ & $14.2 \pm 0.070 * *$ \\
\hline \multirow{4}{*}{ 异 } & Achillea & $7^{\text {th }}$ & 9.5 & $7 . \overline{2 \pm}+0.08$ & $8.05 \pm 0.06^{* *}$ & $8.9 \pm 0.05 * *$ & $7.91 \pm 0.042$ & $11.62 \pm 0.07 * *$ & $8.27 \pm 0.025 * *$ \\
\hline & & $8^{\text {th }}$ & 19 & $7.8 \pm 0.07 * *$ & $8.5 \pm 0.2 * *$ & $9.2 \overline{7} \pm 0.10 * *$ & $8.4 \pm 0.0 .091$ & $12.32 \pm 0.13 * *$ & $8.62+0.075 * *$ \\
\hline & Salix & $9^{\text {th }}$ & 0.0850 & $7.8 \overline{7} \pm 0.04 * *$ & $8.25 \pm 0.05 * *$ & $9.77 \pm 0.02 * *$ & $10.5 \pm 0.40^{* *}$ & $11.77 \pm 0.06^{* *}$ & $13.9 \pm 0.057 * *$ \\
\hline & & $10^{\text {th }}$ & 0.170 & $7.72 \pm 0.04 * *$ & $8.67 \pm 0.07 * *$ & $9.9 \pm 0.07 * *$ & $11 . \overline{1}+0.057$ & $12.85 \pm 0.02 * *$ & $14.42 \pm 0.047 * *$ \\
\hline
\end{tabular}

Table (4): Effect of Achillea millefolium and Salix extracts on sleeping time of thiopental sodium anaesthetized mice (n=5).

\begin{tabular}{|c|c|c|c|c|}
\hline Extract & Plant & Group & Dose (mg/100 gm b.wt) & $\begin{array}{l}\text { Sleeping time } \\
\text { (hour) }\end{array}$ \\
\hline \multirow{2}{*}{ Control } & Achillea & $1^{\text {st }}$ & - & $9.18+0.029$ \\
\hline & Salix & $2^{\text {nd }}$ & - & $9.41 \pm 0.019$ \\
\hline \multirow{4}{*}{ Water } & \multirow{2}{*}{ Achillea } & $3^{\text {rd }}$ & 10.375 & $9.41+0.055^{* *}$ \\
\hline & & $4^{\text {th }}$ & 20.750 & $9.99 \pm 0.033 * *$ \\
\hline & \multirow{2}{*}{ Salix } & $5^{\text {th }}$ & 0.0825 & $9.98 \pm 0.010 * *$ \\
\hline & & $6^{\text {th }}$ & 0.165 & $11.0+0.225^{* *}$ \\
\hline \multirow{4}{*}{ Ethanolic } & \multirow{2}{*}{ Achillea } & $7^{\text {th }}$ & 9.5 & $9.32 \pm 0.058 * *$ \\
\hline & & $8^{\text {th }}$ & 19 & $9.52+0.012 * *$ \\
\hline & \multirow{2}{*}{ Salix } & $9^{\text {th }}$ & 0.0850 & $10.51+0.012 * *$ \\
\hline & & $10^{\text {th }}$ & 0.170 & $11.22+0.012 * *$ \\
\hline
\end{tabular}


back pain. Achillea millefolium (watery and ethanolic extracts) produced a significant increase in sleeping time at doses of 10.375 , 20.750 and 9.5, $19 \mathrm{mg} / 100 \mathrm{gm}$ b.wt., respectively. The central nervous system depressant activity of Achillea millefolium may be attributed to the volatile oil present in the extracts (Christine, 2003).

Both watery and ethanolic extracts of Achillea millefolium and Salix posses an antiinflammatory effect as indicated by decreasing thickness of paw in rats post-administration. The most active fractions isolated from Achillea millefolium flower heads posses antiinflammatory activity that reduced the inflammation in mice by $35 \%$ (Goldberg et al., 1969). Most of species are widely used as anti-inflammatory and this effect may be due to the flavonoids present (Valant-Vetscheram, and Wollenweber 1988).

The anti-inflammatory effect of Salix explained by (Masika et al., 1997; Schilcher, 2000 and Krivoy et al., 2001). They were mentioned that white willow bark (Salix alba L) contains a variety of chemical constituents. The main one studied being salicin which is metabolically converted in the body to the aspirin metabolite, salicylic acid. Salicylates have anti-inflammatory effect in the body.

From the aforementioned results, watery and ethanolic extracts of both Achillea millefolium and Salix could be used as an anti-inflammatory, antipyretic and analgesic.

\section{References}

Alperman, H. (1972): Bericht Uber Pharmakologische untersuchungen mit fenbendazol. Abteilung fur pharmakologie, pp. 863-1.

Chandler, R. F.; Hooper, S. N.; Hooper, D. L.; Jamieson, D. W. and Flinn, C. G. (1982): Herbal remedies of the maritime Indian: sterols and triterpenes of Achillea millefolium L (Yarrow). J. Pharm. Sci., 7(1): 690693.

Chaplins'ka, M. G. and Golovkin, V. A. (1962): Antimicrobial action of some extracts. Farma Tsevt. Zh., 18 (2): 56-60.

Christine, H. (2003): Achillea millefolium (L) Copyright 2001-2003, email woldform purplesage Org. UK.

Eisenberg, E.; Chrubasik, S. and Balan, E. (2000): Dose-dependent alleviation of low back pain with salix ${ }^{\circledR}$, a special willow bark extract. $3^{\text {rd }}$ International Congress on phytomedicine, Munich, Germany, Phytomedicine, (7 suppl.) 2: 39 .

Goldberg, A. S.; Mueller, E. C.; Eigen, E. C. and Desalva, S.J. (1969): Isolation of the anti-inflammatory principles from Achillea millefolium (Compositae). J. Pharm. Sci., 58(8): 938-941.

Heide, L.; Schmid, B. and Kotter, I. (2000): Pharmacokinetic and clinical efficacy studies on a standardized willow bark extract. $3^{\text {rd }}$ International Congress on phytomedicine, Munich, Germany, Phytomedicine, (7 suppl.) 2: 38 .

Jacob, J. and Bosovski, M. (1961): Cited from Turner, R.A. "Screening methods in pharmacology". Academic Press INC, New York and London, pp. 104.

Janssen, P. A. and Jageneau, A. (1957): A new series of potent analgesics: part I, chemical structure and pharmacological activity. J. Pharmacol., 9: 381.

Kolodziej, H. (1990): Oligomeric flavan-3-ols from medicinal willow bark. Phytochemistry, 29 (3): 955-960.

Krivoy, N.; Pavlotzky, E.; Chrubasik, S.; Eisenberg, E. and Brook, G. (2001): Effect of salices cortex extract on human platelet aggregation. Planta Medica., 67 (3): 209212.

Kudrica, F. W. and Glowniak, D. (1967): Action and highly antipyretic action of yarrow. Chem. Abstr., 67:62837.

Levine, R. R. (1978): Pharmacology: Drug action and reactions. $2^{\text {nd }}$ ed. Little, Brown and Company Boston, pp. 359-458.

Masika, P.J.; Sonandi, A.; Averbeke, W.V. and VanAverbeke, W. (1997): Perceived causes, diagnosis and treatment of babesiosis and anaplasmosis in cattle by livestock farmers in communal areas of the central eastern Cape Province South Africa. J. South Africa Vet. Asso., 68 (2): 40-44.

Petcu, P. and Andoronescu (1978): Yarrow (Achillea millefolium). Op. Cit., pp 266-267.

Randall, A. S. and Sellitto, C. E (1957): Cited in selected topics in experimental pharmacology by sheath, Dadkar and Kamato. The Kolhari book shop, Parel. Bombay (India), $1^{\text {st }}$ ed., 134.

Schilcher, H. (2000): Efficient phytotherapy. Antiinflammatory herbal remedies. Herba-Polonica, 46 (2): 105-110.

Snedecor, G.W. (1969): "Statistical Methods", $4^{\text {th }}$ ed. The Iowa State Univ. Press. Ames, Iowa, USA, page 91.

Teotino, U. M.; Fris, L. P.; Gandini, A. and Della Bella, D. (1963): Thio-derivatives of 2,3 dihydro-4, 4-1, 3bezoxazin-4-one synthesis and pharmacological properties. J. Med. Chem., 6: 248.

Thapliyal, R. P. and Bahuguna, R. P. (1993): Fatty acids of flavonoids of salix lindleyana. Int. J. Pharmacognosy, 31(2): 165-166.

Tierra, N. E. and Lesley, P. L. (1992): The herbs of life. The Crossing Press, Freedom CA, 1912.

Valant-Vetscheram, K. M. and Wollenweber, E. (1988): Leaf flavonoids of the Achillea millefolium group. Part II. Distribution patterns of free aglycones in leaf exudates. Biochemical-Systematics-and- Ecology, 16(7-8): 605-614.

Whang, W. K.; Chang, Y. S. and Kim, P. H. (1995): Phenolic compounds from the bark of salix gilgiana. J. Pharmac.. Soc. Kor., 39(2): 193-199.

Winter, C.; Risely, E. and Nuss, G. W. (1962): Coragenin induced oedema in hind paw of the rat as an assay for antiinflammatory drugs. Proc. Soc. Exp. Biol. Med., 3: 544-5 


\section{تأثير نباتي الأخيليا (ذات الألف ورقة) والصفصاف كمضاد للالتهاب ، خافض للحرارة ومسكن للألم}

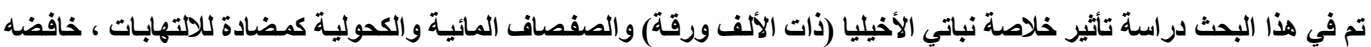

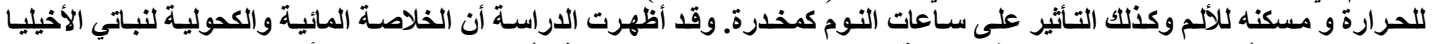

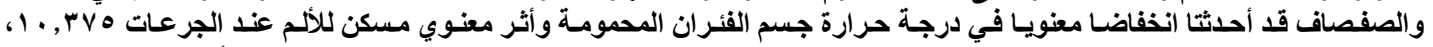

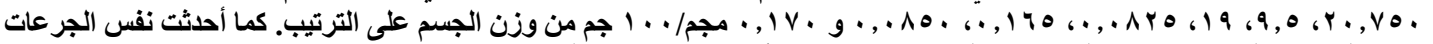

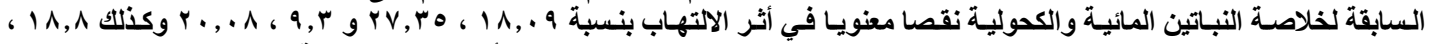

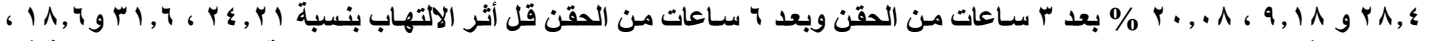
س

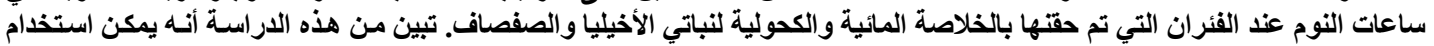

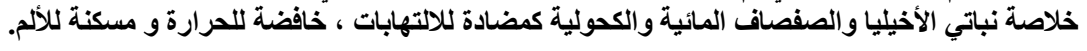

